\title{
PEMBELAJARAN INTERDISIPLINER: UPAYA MENGAPRESIASI SASTRA SECARA HOLISTIK
}

\author{
Daru Kabeka Janarto \\ English Department, Faculty of Language and Culture, Bina Nusantara University, \\ Jln. Kemanggisan Ilir III No. 45, Kemanggisan/Palmerah, Jakarta Barat 11480 \\ djanarto@binus.edu
}

\begin{abstract}
The research is regarding 4 class cycle about interdisciplinary teaching technique of literature teaching in BINUS International School Simprug, Jakarta. The interdisplinary teaching is done in grade 10 in 3 subjects of Indonesian Language and Literature, Computer (IT), and Visual Arts. The teaching topic is Ma Yan, a novel about Muslim teenager who struggles for education in Zhang Jiashu, a remote village in China. This teaching climax is talk show with the writer of Ma Yan and its publisher followed with visual arts show from the students. The observation result shows that talent and involvement of students are high through the learning materials, proved by assignments done in time and their antusiasm towards their projects and assignments.
\end{abstract}

Keywords: interdisciplinary teaching, Ma Yan, students

\begin{abstract}
ABSTRAK
Tulisan ini merupakan Penelitian Tindakan Kelas 4 siklus mengenai tehnik pembelajaran interdisipliner dalam pengajaran sastra di Binus International School Simprug, Jakarta. Pembelajaran interdisipliner ini dilaksanakan di kelas 10 dengan melibatkan tiga mata pelajaran: Bahasa dan Sastra Indonesia, Komputer (IT), dan Visual Arts. Topik pembelajaran adalah Ma Yan, sebuah novel yang berkisah tentang remaja muslim yang berjuang demi pendidikan di desa Zhang Jiashu, yang terpencil di Cina. Klimaks pembelajaran berupa talk show dengan penulis Ma Yan dan penerbitnya yang diikuti dengan pameran karya visual yang siswa hasilkan. Hasil observasi pembelajaran menunjukkan bahwa minat dan keterlibatan siswa sangat tinggi terhadap materi yang dipelajari, ditunjukkan dengan tugas yang diselesaikan tepat waktu dan antusisme dalam menyelesaikan tugas dan proyek mereka.
\end{abstract}

Kata kunci: pembelajaran interdislipiner, Ma Yan, siswa 


\section{PENDAHULUAN}

Baru-baru ini, harian Kompas dalam satu artikelnya menyoroti dekadensi nilai rata-rata mata pelajaran Bahasa Indonesia dalam Ujian Nasional. Salah satu faktor yang disinyalir sebagai pemicu masalah ini adalah munculnya anggapan bahwa Bahasa Indonesia tidak begitu penting, dan lebih menyedihkan lagi bahkan dianggap remeh sehingga murid tidak serius mempelajarinya (THY, 2010). Setali tiga uang dengan pelajaran Bahasa Indonesia, nasib pelajaran sastra bahkan lebih menyedihkan. Selama ini pelajaran sastra, yang semata-mata menumpang pada pelajaran Bahasa Indonesia dan diberikan hanya 2-3 jam per minggu, selain dianggap kurang penting dibandingkan dengan mata pelajaran eksakta seperti matematika dan sains misalnya, juga terisolir dalam pelajaran humaniora lainnya. Hal ini sejalan dengan permasalahan dalam makalah yang dikemukakan sastrawan Ahmadun Yosi Herfanda (2007) yang merasa prihatin dengan minimnya pengajaran sastra di sekolah. Sinyalemen ini diindikasikan oleh rendahnya apresiasi dan minat baca siswa terhadap karya sastra.

Di samping kurangnya ketersediaan buku bacaan sastra, surutnya animo peserta didik dalam mempelajari sastra dan mengapesiasi karya sastra juga tidak luput dari permasalahan instruksional (Ardianto, 2007). Pendekatan yang kurang tepat, bahkan cenderung tradisional dalam pembelajaran sastra yang dilakukan sekedar untuk memenuhi tuntutan kurikulum, turut menyurutkan motivasi belajar para peserta didik. Dalam prakteknya, pelajaran sastra diperlakukan sebatas pengetahuan saja dengan menghapalkan sejumlah tokoh-tokoh sastra (pengarang), penyair serta karya-karya dan tahun penerbitannya. Tak jarang pula buku catatan siswa dipenuhi serentetan teori sastra serta sejumlah ringkasan sinopsis cerita yang mungkin sebagian besar bahkan tak pernah dilihat atau dibacanya.

Sementara itu, suasana pembelajaran yang terjadi dalam ruang yang dikelilingi dinding kelas dimonopoli oleh guru dengan menjejalkan pengetahuannya. Siswa jarang diajak untuk ikut terlibat. Dalam kondisi demikian menurut Putu Wijaya, "yang terjadi bukan proses pembelajaran tetapi penderaan. Murid-murid disiksa untuk menelan, menghapal, apa yang dimuntahkan oleh guru tanpa mampu memaknai apa hakekat pengetahuan yang diterimanya.” Akibatnya, pelajaran yang idealnya menarik dan besar manfaatnya itu terasa monoton, berat dan kering. Hasilnya, daya imajinasi dan kreasi siswa kurang optimal perkembangannya. Alih-alih mengembangkan kemampuan berpikir kritis, pembelajaran sastra seperti itu hanya membuahkan peserta didik yang berpikir reaktif. Inilah problematika dalam pengajaran sastra di sekolah.

Ruang lingkup mata pelajaran Sastra Indonesia di tingkat SMA terdiri atas aspek pengetahuan kesastraan dan apresiasi sastra. Pengetahuan sastra lekat dengan faktor yang bersifat informatif, sedangkan kegiatan apresiasi sastra mencakup dua faktor yang lebih kompleks, yang bersifat reseptif dan produktif. Keduanya berhubungan dengan empat keterampilan berbahasa yaitu: mendengarkan, berbicara, membaca, menulis. Materi yang dipelajari pun meliputi berbagai genre, baik yang bersifat modern maupun klasik. Dalam kurikulum IB (International Bacalaureatte) program Diploma, bahkan dicantumkan karya sastra terjemahan (literatur dunia-world literature) sebagai daftar bacaan wajib. Dengan demikian, dapat disimpulkan bahwa pembelajaran sastra dan kegiatan apresiasi sastra merupakan pelajaran yang besar manfaatnya. Selain aspek kognitif, apresiasi sastra dapat meningkatkan keterampilan berpikir tingkat tinggi (analitis, sintesis dan kreatif) serta meningkatkan aspek afektif dengan cara membentuk sifat-sifat mulia pada diri peserta didik, seperti: kearifan, kesantunan, kerendah-hatian, keadilan dan kepedulian pada nasib sesama; serta mewariskan nilai-nilai luhur budaya bangsa untuk membentuk jati diri siswa sekaligus jati diri bangsa; menumbuhkan sikap apresiatif serta minat baca terhadap karya sastra.

Sayangnya, pada prakteknya di lapangan, pembelajaran sastra lebih difokuskan pada aspek pengetahuan kesastraan daripada apresiasi sastra. Alasannya, mengajarkan apresiasi sastra pada peserta didik jelas lebih rumit dan membutuhkan waktu lebih panjang dibanding mengajarkan 
pengetahuan sastra. Selain itu, dibutuhkan kesabaran, wawasan pengetahuan yang memadai serta kecakapan khusus dalam mengajarkan apresiasi sastra. Absennya faktor-faktor ini menjadi sinyalemen disorientasi pelajaran sastra di sekolah yang pada gilirannya berimbas negatif terhadap prestasi belajar siswa.

Setidaknya ada 4 fakta yang ditemukan peneliti pada setting penelitian selama proses observasi, yakni: (1) siswa cenderung memperlihatkan perilaku pasif dalam kegiatan interaksi guru dengan siswa, siswa dengan siswa, serta antara siswa dengan sumber belajar. Bila diberi kesempatan untuk tanya jawab di akhir sesi pelajaran, hanya sebagian peserta didik yang merespon. Demikian pula pada saat diskusi kelompok. Tidak banyak yang memberikan tanggapan terhadap topik permasalahan yang didiskusikan (2) tugas-tugas tagihan yang sedianya dikerjakan oleh siswa sering tidak diserahkan tepat waktu. Tugas untuk membaca sumber belajar (karya sastra) di rumah tidak dilakukan dengan alasan minimnya minat baca serta tidak mengerti apa yang dibaca. (3) Dalam proses belajar mengajar, adakalanya secara bergantian, siswa meninggalkan kelas dengan alasan ke kamar kecil. Beberapa di antaranya mengerjakan tugas lain saat KBM berlangsung. (4) Tak ketinggalan pula kontribusi guru yang kurang memberikan variasi dalam pelajaran.

Uraian di atas memperlihatkan bahwa tantangan utama yang dihadapi para pengajar sastra saat ini adalah bagaimana menumbuhkembangkan kecintaan dan ketertarikan siswa terhadap sastra. Untuk menjawab tantangan itu, guru harus dapat membuktikan bahwa apa yang diajarkan itu bermanfaat. Tanpa melihat, merasakan manfaat serta menyadari kaitan sastra dengan realita kehidupan, maka pelajaran tersebut akan kembali dianaktirikan. Agar pengajaran sastra benar-benar membawa manfaat bagi peserta didik, selain "berkomunikasi” langsung dengan karya sastra yang dipelajari, menurut T. Suharianto (2009), siswa perlu mendapatkan 2 pengalaman bersastra; yaitu (1) pengalaman mengapresiasi dengan merasakan indahnya karya tersebut dan (2) pengalaman berekspresi dalam mengungkapkan pikiran dan perasaannya melalui karya sastra.

Senada dengan itu, Taufik Ismail (2009), sastrawan serta pemerhati sastra menambahkan, bahwa siswa perlu dibimbing memasuki sastra secara asyik, nikmat dan gembira. Pendekatan yang dilakukan selain harus membentuk citra sastra sebagai sesuatu yang menyenangkan, juga harus menimbulkan sikap antusias sehingga peserta didik merasa memerlukannya. Salah satu metode yang mengakomodir kondisi dan pengalaman belajar ini adalah melalui pembelajaran terpadu dengan mengkaitkan beberapa aspek antar pelajaran (interdisipliner) dalam satu tema (fokus) pembelajaran.

\section{METODOLOGI PENELITIAN}

Berdasarkan latar belakang serta identifikasi masalah di atas, permasalahan dalam Penelitian Tindakan Kelas (PTK) ini yaitu: Bagaimana menerapkan pembelajaran sastra (apresisiasi sastra) yang mengasikkan dan menyenangkan agar dapat meningkatkan motivasi serta keterlibatan siswa dalam proses belajar mengajar? Bagaimana proses pelaksanaan pembelajaran sastra yang menyenangkan dan mengasyikan melalui unit pembelajaran interdispiliner (terpadu)? Sejauhmana efektivitas unit pembelajaran interdisipler (terpadu) berpengaruh terhadap hasil belajar serta kemampuan apresiatif sastra yang holistik (verbal, lisan dan visual)?

Solusi atas permasalahan dalam PTK ini adalah menerapkan model pembelajaran terpadu atau pendekatan lintas displiner. Pelaksanaannya dilakukan dengan menggunakan pengajaran unit tematis yang melibatkan disiplin di luar sastra yaitu teknologi komputer serta seni visual (visual arts).

Tujuan dan manfaat penelitian ini yaitu untuk meningkatkan pemikiran kritis guru dalam mencari alternatif solusi pemecahan masalah yang ditemukan di kelas; meningkatkan strategi serta kualitas pembelajaran sastra; meningkatkan minat serta apresiasi siswa terhadap pelajaran sastra serta 
mengembangkan daya nalar dan ketrampilan berkolaborasi; mempromosikan dan menerapkan pembelajaran holistik sehingga siswa mampu menemukan kaitan-kaitan yang relevan antar bidang studi melalui tugas dan proyek interdisiplin: bahasa, tehnologi, dan seni visual; dan agar siswa mampu menyampaikan gagasan, nilai-nilai dan keyakinan melalui bahasa dan media visual.

\section{PEMBAHASAN}

\section{Hakikat Pembelajaran Interdisipliner}

Pembelajaran interdisipliner bukan tren baru dalam pendidikan. Menurut Prihantoro dalam Trianto (2007), bermula dari Konferensi Internasional Pembelajaran Sains Terpadu pertama yang diselenggarakan di Varna (Bulgaria), model pembelajaran yang diusulkan oleh para penulis dan penyusun kurikulum pembelajaran Sains ini kemudian berkembang dalam berbagai kurikulum di seluruh dunia. Di Indonesia, strategi pembelajaran dengan menggunakan pendekatan tematik ini sebenarnya telah diisyaratkan sejak kurikulum 1994. Akan tetapi karena keterbatasan kemampuan guru serta kurangnya pelatihan, pembelajaran terpadu tidak dapat diwujudkan dengan baik.

Model pembelajaran terpadu kembali diusung dalam paket kurikulum KBK (Kurikulum Berbasis Kompetensi) namun dengan istilah yang agak berbeda yaitu model pembelajaran tematik. Istilah ini gunakan karena pada prakteknya pembelajaran terpadu dirancang berdasarkan tema tertentu. Dengan kata lain, pembelajaran terpadu adalah kegiatan mengajar yang dilakukan dengan memadukan materi beberapa mata pelajaran dalam satu tema (Sukandi, 2001). Dalam pembahasannya, tema tersebut akan menjadi topik/fokus pembahasan atau gagasan pokok yang menjadi kajian utama dalam pembelajaran.

Selain pembelajaran terpadu atau pembelajaran tematik. Istilah lain yang sering digunakan adalah pembelajaran interdisipliner. Jacobs seperti dikutip dalam Indrawati (2009) mendefinisikan pembelajaran interdispliner sebagai "Pendekatan kurikula yang menerapkan metodologi dari lebih satu displin ilmu untuk mengkaji tema, isu, pemasalahan dan topik sentral.” Pandangan ini sejalan dengan pendapat Everett (dalam Indrawati, 2009) yang melihat pembelajaran interdisipliner sebagai pendekatan pembelajaran yang memadukan beberapa mata pelajaran ke dalam suatu proyek aktif. Dengan demikian, secara umum sebuah pembelajaran interdisiplner mencakup: (1) kombinasi mata pelajaran; (2) penekanan pada proyek; (3) keterkaitan antarkonsep dan (4) tema sebagai prinsip organisasi atau sumber kajian.

\section{Kelebihan Pembelajaran Interdispliner}

Kunandar (2007) menegaskan bahwa pembelajaran interdisipliner (terpadu) memberikan pengalaman belajar yang menyenangkan karena berangkat dari minat dan kebutuhan peserta didik. Terlebih bila gagasan pokok pembahasan tersebut merupakan suatu persoalan yang dekat dengan lingkungan mereka. Dengan demikian, hasil belajar dapat bertahan lama karena pengalaman belajar tersebut lebih berkesan dan bermakna. Kebermaknaan itu, menurut Joni T.R. dalam Trianto (2007), tercipta sebab siswa secara aktif mencari, menggali serta menemukan konsep keilmuan secara holistik dengan cara memahami konsep yang baru dipelajari dan menghubungkannya dengan konsep lain yang telah dipahami. Pembelajaran terpadu tidak saja memberikan kontribusi positif pada peserta didik, tetapi juga kepada pendidik. Tabel berikut ini (Tabel 1) menyajikan keuntungan pembelajaran terpadu bagi pendidik dan peserta didik. 
Tabel 1 Manfaat Pembelajaran Terpadu

\begin{tabular}{|c|c|}
\hline Peserta didik & Pendidik \\
\hline $\begin{array}{l}\text { 1. Menghemat waktu dalam mempelajari konsep yang kompleks } \\
\text { (sulit) serta hemat waktu dalam menuntaskan tugas-tugas } \\
\text { yang diberikan. }\end{array}$ & $\begin{array}{l}\text { 1. Menghemat waktu dalam mengajarkan konsep } \\
\text { yang kompleks (sulit). }\end{array}$ \\
\hline $\begin{array}{l}\text { 2. Mengembangkan } 3 \text { ranah sasaran pendidikan yaitu : kognitif, } \\
\text { pskomotik serta afektif }\end{array}$ & $\begin{array}{l}\text { 2. Mengembangkan serta meningkatkan ranah } \\
\text { kognitif serta keterampilan sosial; kolaborasi }\end{array}$ \\
\hline $\begin{array}{l}\text { 3. Menemukan hubungan antara konsep satu dengan lainnya } \\
\text { hingga meningkatkan pemahaman. }\end{array}$ & $\begin{array}{l}\text { 3. Tema atau pokok pikiran yang menjadi } \\
\text { penghubung antar mata pelajaran dapat diajarkan } \\
\text { secara logis dan alami }\end{array}$ \\
\hline $\begin{array}{l}\text { 4. Mengembangkan keterampilan menemukan, mengolah dan } \\
\text { memanfaatkan informasi. }\end{array}$ & $\begin{array}{l}\text { 4. Memberdayakan keterampilan mengajar } \\
\text { (teaching skills) }\end{array}$ \\
\hline Mengembangkan wawasan berpikir yang holistik dan luas. & $\begin{array}{l}\text { 5. Membantu siswa melihat masalah, situasi } \\
\text { dan topik dari berbagai perspektif. }\end{array}$ \\
\hline
\end{tabular}

\section{Karakteristik Pembelajaran Interdisipliner}

Karakteristik Pembelajaran Terpadu yang dikemukakan oleh Sukayati (2004) dan Margareta dalam Indrawati (2009), yaitu holistik, bermakna, aktif, dan otentik. Holistik yaitu tema yang menjadi alat pemersatu materi yang beragam dari beberapa materi pelajaran dikaji dari berbagai situasi, aspek dan perspektif. Bermakna yaitu tema yang dikaji dari berbagai sisi dan perspektif akan membentuk jalinan konsep yang saling berhubungan (skemata). Pembelajaran menjadi bermakna manakala siswa dapat mengkaitkan satu konsep dengan konsep lainnya dan digunakan untuk memecahkan permasalahan yang dihadapi dalam kehidupan yang nyata.

Pembelajaran terpadu berpusat pada keaktifan peserta didik dalam mencari, menggali dan menemukan konsep pengetahuan. Keaktifan secara fisik, mental, intelektual dan emosional ini akan memampukan siswa mencapai hasil belajar yang optimal serta termotivasi untuk belajar. Sedangkan, otentik bermakna pengetahuan/konsep/hasil belajar yang diperoleh siswa dalam pembelajaran terpadu ditemukan oleh siswa sendiri karena ia melibatkan dirinya secara langsung dalam proses pembelajaran serta mencarinya sendiri. Penemuannya merupakan sesuatu yang otentik, dan bukan atas informasi dari guru. Mengingat guru dalam hal ini hanya berperan sebagai fasilitator dan katalisator.

\section{Pengorganisasian Kurikulum}

Dalam pembelajaran interdisipliner, hubungan antar mata pelajaran dapat dipetakan dalam 3 tipe yaitu Separated Subject Curriculum, Correlated Curriculum dan Intergrated Curriculum. (Nasution, S. dalam Trianto, 2007). Dalam Integrated curriculum, pembelajaran pusatkan pada suatu masalah atau topik tertentu yang dilaksanakan melalui pembelajaran unit. Untuk memecahkan masalah tersebut, peserta didik diarahkan untuk melakukan kegiatan yang saling berhubungan antara satu mata pelajaran dengan mata pelajaran lainnya. Berdasarkan pengertian di atas, maka pembelajaran interdispliner Bahasa dan Sastra, Teknologi serta Seni Visual dapat digambarkan (Gambar 1) sebagai berikut:

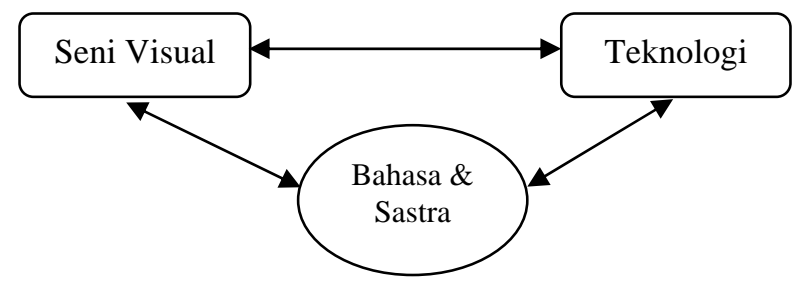

Gambar 1 Kurikulum terintegrasi 


\section{Model Pembelarajaran Interdisipliner}

Fogarty (1999) memperkenalkan berbagai model pembelajaran interdisipliner antara lain: model hubungan, model jaring laba-laba, model terpadu dan model tersarang. Dalam pembelajaran terpadu yang menggunakan pendekatan tematik, model jaring laba-laba (webbed) sering digunakan. Dalam pembelajaran ini, kegiatan belajar-mengajar dimulai dengan tema sentral. Selanjutnya tema tersebut dijabarkan dalam pokok bahasan, keterampilan, konsep serta kemampuan yang hendak dikembangkan oleh siswa dalam berbagai mata pelajaran. Harapannya siswa memiliki pengetahuan yang utuh melalui hubungan antarkegiatan dalam mata pelajaran yang berbeda. Kelebihan model ini menurut Trianto (2007) dapat meningkatkan motivasi belajar anak didik, terutama bila tema yang dipilih sesuai dengan minat dan kebutuhan mereka serta masih dalam jangkauan pemikiran mereka.

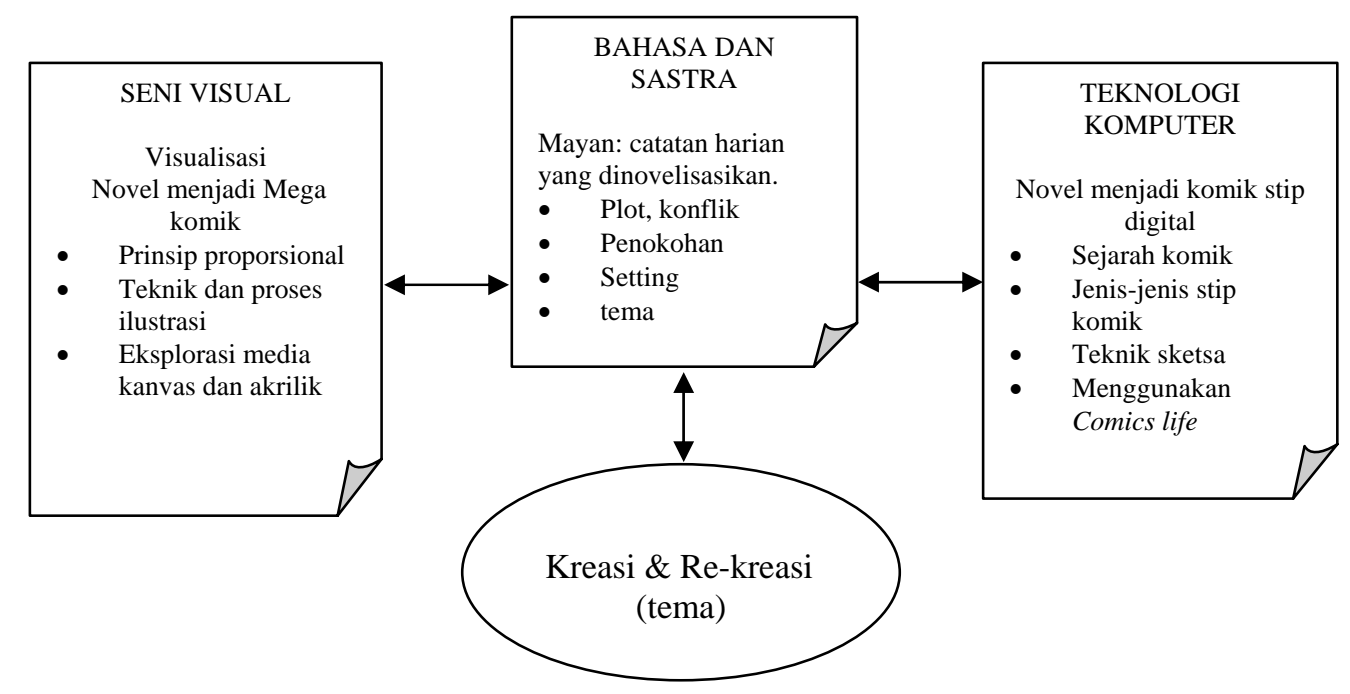

Gambar 2 Pembelajaran Interdisipliner Model Jaring Laba-laba (webbed)

\section{Setting Penelitian dan Subjek Penelitian}

PTK (Penelitian Tindakan Kelas) ini dilaksanakan di Binus International School Simprug, Jakarta Selatan dalam kegiatan belajar-mengajar mata pelajaran Language A - Indonesian Language and Literature (Bahasa dan sastra Indonesia), Technology (Teknologi komputer) serta Visual Arts yang mengadopsi kurikulum IB-MYP (International Baccalaureate Middle Years Program). Kegiatan penelitian dilakukan pada kuartal ke-3 yang berlangsung dari Januari-Maret 2010. Subjek penelitian adalah siswa kelas X, sebanyak 107 orang, yang terdistribusi dalam 5 kelas bahasa dan sastra yang paralel. Adapun distribusinya adalah: kelas 10A sebanyak 19 orang, 10B sebanyak 22 orang, 10C sebanyak 20 orang, 10D sebanyak 22 siswa dan 10E sebanyak 24 orang.

Sumber data dalam penelitian ini adalah siswa (subjek penelitian) untuk memperoleh data tentang hasil belajar dan aktivitas siswa dalam kegiatan belajar-mengajar dan rekan sejawat (Pengajar sastra, Seni visual serta Teknologi) untuk melihat tingkat keberhasilan implementasi pembelajaran terpadu, baik dari sisi siswa maupun guru.

Teknik pengumpulan data yang digunakan yaitu tes, untuk mendapatkan data hasil belajar siswa; observasi digunakan untuk mengumpulkan data tentang aktivitas, partisipasi serta motivasi subjek penelitan dalam KBM serta implementasi pembelajaran tematik; diskusi antarrekan sejawat, kolaborator untuk refleksi hasil siklus PTK; refleksi untuk mendapatkan balikkan (feedback) serta pendapat subjek penelitian terhadap unit pembelajaran tematik. 
Alat pengumpul data dalam penelitian ini adalah tes, menggunakan butir soal untuk mengukur hasil belajar siswa; observasi, menggunakan lembar observasi dengan menggunakan daftar cek dan skala nilai; diskusi, menggunakan lembar hasil pengamatan; kuesioner, menggunakan daftar pertanyaan.

Data yang dikumpulkan selama 4 siklus PTK ini dianalisis secara deskriptif dengan menggunakan teknik persentase untuk melihat kecenderungan yang terjadi dalam kegiatan pembelajaran. Hasil belajar dilakukan dengan menganalisis nilai-rata kuis, presentasi lisan serta resensi novel yang disajikan dalam tabel. Aktivitas subjek penelitian dilakukan dengan menganalisis tingkat keaktifan siswa dalam proses belajar mengajar serta aktivitas guru dalam mengimplementasi pembelajaran terpadu. PTK yang berlangsung selama 4 siklus ini merupakan penelitian tindakan kelas partisipatoris yang menggunakan model John Elliot. Peneliti berkolaborasi dengan pengajar bahasa dan sastra kelas X sekaligus turut serta dalam melakukan tindakan penelitian.

\section{Tindakan Penelitian}

Tabel 2 Tahapan Penelitian Tindakan Kelas Pembelajaran Interdisipliner

\section{SIKLUS 1}

SIKLUS 2

A. Perencanaan

1. Menetapkan bidang studi (mata pelajaran) yang akan dipadukan setelah berdiskusi dan memperhatikan presentasi dari guru bidang studi yang bersangkutan. Dalam penelitian ini, pembelajaran terpadu akan diaplikasikan dalam mata pelajaran Bahasa dan sastra, Teknologi serta Seni Visual.

2. Melakukan pemetaan terhadap standar kompetensi, kompetensi dasar serta indikator ketiga mata pelajaran yang dipadukan.

3. Merumuskan tema sebagai pemersatu antar mata pelajaran serta matrik keterhubungannya (jaringannya).

4. Menyusun silabus yang meliputi materi-materi, strategi, media dan sarana penunjang pembelajaran serta bentuk evaluasi.

5. Menyusun rencana pembelajaran serta menyiapkan hal-ha yang telah dirancang dalam silabus.

6. Merancang dan membuat instrumen penelitian yang digunakan dalam PTK

B. Pelaksanaan

1. Memberikan penjelasan mengenai unit pembelajaran terpadu/interdisiplner serta materi dan aktivitas pembelajaran.

2. Tindakan 1: Siswa melakukan investigasi yang lebih detail mengenai latar belakang (setting); keadaan geografis, jumlah penduduk serta tingkat pendidikan yang berkenaan dengan materi belajar serta catatan harian Ma Yan.

3. Tindakan 2: Melaporkan hasil eksplorasi

4. Tindakan 3: Diskusi kelas merelasikan hasil ekspolasi dengan isi novel

C. Observasi

1. Situasi kegiatan belajar mengajar

2. Keaktifan siswa

D. Refleksi dan evaluasi

1. Tes informatif kuis Ma Yan (bab 1-10)

1. Peneliti dan kolabolator melakukan diskusi dan refleksi atas hasil observasi selama KBM berlangsung.

2. Mencatat hasil penelitian dan membuat rancangan pada siklus kedua.
A. Perencanaan

1. Membuat rencana belajar berdasarkan hasil refleksi pada siklus pertama.

2. Menyiapkan media belajar berupa video (fim documenter)

B. Pelaksanaan

1. Tindakan 1: Membaca novel dan mendiskusikan MAYAN (bab 11-20) dengan metode pengelajaran kooperatif tipe Jigsaw

2. Tindakan 2: Menonton film dokumenter Ma Yan yang diikuti dengan diskusi.

3. Tindakan 3: Menjelaskan secara langsung serta mencontohkan cara menggambar sketsa wajah, gerak tubuh dan ekspresi. Metode yang digunakan: pembelajaran langsung direct instructional.

C. Observasi:

1. Situasi kegiatan belajar mengajar

2. Keaktifan siswa

3. Presentasi lisan

\section{Refleksi dan evaluasi}

1. Peneliti dan kolabolator melakukan diskusi dan refleksi atas hasil observasi selama KBM siklus 2 berlangsung.

2. Mencatat hasil penelitian dan membuat rancangan pada siklus ketiga. 
Tabel 2 Tahapan Penelitian Tindakan Kelas Pembelajaran Interdisipliner (lanjutan)

\section{SIKLUS 3}

SIKLUS 4

\section{A. Perencanaan}

1. Membuat rencana belajar berdasarkan hasil refleksi pada siklus kedua

2. Menyiapkan media belajar (kanvas dan cat akrilik)

\section{B. Pelaksanaan}

1. Tindakan 1 : Role Play satu bab dari bagian novel

2. Tindakan 2 : Memberikan teori resensi novel

3. Tindakan 3 : membagi kelompok dan memulai proyek

4. Mengadakan workshop komik yang dibawakan oleh pembicara ahli/ komikus dan diikuti dengan design/sketsa komik 3 set (Tindakan 2, 3 kali tatap Observasi: muka)

1. Situasi kegiatan belajar mengajar

2. Keaktifan siswa

3. Penilaian hasil belajar berupa komentar lisan.

C. Refleksi dan evaluasi

1. Peneliti dan kolabolator melakukan diskusi dan refleksi atas hasil observasi selama KBM siklus 3 berlangsung.

2. Mencatat hasil penelitian dan membuat rancangan pada siklus keempat
A. Perencanaan

1. Membuat rencana belajar berdasarkan hasil refleksi pada siklus ketiga

2. Menyiapkan media belajar kanvas

\section{B. Pelaksanaan}

1. Bahasa Indonesia: Menyelesaikan karya visual secara berkelompok.

2. Menyeleksi draft komik terbaik dan menyempurnakannya dengan menggunakan perangkat lunak komputer comics life

3. Membuat komik raksasa di atas kanvas.

Observasi:

1. Situasi kegiatan belajar mengajar

2. Keaktifan siswa

3. Penilaian hasil belajar berupa resensi novel

C. Refleksi dan evaluasi

1. Peneliti dan kolabolator melakukan diskusi dan refleksi atas hasil observasi selama KBM di siklus 3 berlangsung.

2. Mencatat hasil penelitian serta menyimpulkannya

Penelitian ini berlangsung dalam 4 siklus yang masing-masing terdiri dari 3 tahap yaitu perencanaan, tindakan dan observasi serta refleksi dan evaluasi. Hasil tindakan keseluruhan siklus terhadap aktivitas guru dalam menerapkan pembelajaran interdisipliner serta aktivitas belajar siswa dan hasil belajarnya, disajikan pada tabel berikut ini (Tabel 3).

Tabel 3 Implementasi Pembelajaran Interdisipliner

\begin{tabular}{ccccc}
\hline Aspek & Siklus I & Siklus II & Siklus III & Siklus IV \\
\hline Aktivitas guru & $67.8 \%$ & $70.2 \%$ & $76.6 \%$ & $78.4 \%$ \\
Aktivitas Siswa & $66.3 \%$ & $73.4 \%$ & $81.4 \%$ & $87.3 \%$ \\
Hasil Belajar & $55.2 \%$ & $65.2 \%$ & $70.4 \%$ & Non tes \\
\hline
\end{tabular}

\section{Siklus 1}

Tema yang disepakati oleh peneliti dan kolaborator adalah "kreasi dan re-kreasi". Tema ini disesuaikan dengan tahap perkembangan kognitif subjek penelitian yang berada pada ranah operasional formal, sehingga memungkinkan mereka untuk melihat hubungan keterkaitan antara konsep yang dipelajari dalam ketiga mata pelajaran yang terkait. Hal ini seturut dengan pemikiran Piaget bahwa proses belajar seseorang mengikuti pola dan tahapan perkembangan sesuai dengan umurnya (Asri, 2005). Sumber tema berasal dari karya sastra yang berjudul Ma Yan, yang dialihbentukkan dari catatan harian menjadi novel oleh Sanie B. Kuncoro. 
Tindakan pada siklus pertama didahului dengan penjelasan mengenai pembelajaran intedisipliner, tema, tujuan pembelajaran serta kegiatan pembelajaran. Kebermaknaan pelajaran diawali peserta didik dengan mengetahui tujuan yang akan dicapai serta manfaatnya. Hal ini menimbulkan motivasi belajar. Perilaku ini terekam dalam catatan observasi di lapangan serta dokumentasi foto. Subjek penelitian mendengarkan dan mengikuti penjelasan guru dengan serius dan mengajukan pertanyaan dengan antusias. Ada 10 pertanyaan yang diajukan. Di antaranya: "Bagaimana sistem penilaian hasil belajarnya?" "Apa isi materi utama yang akan dipelajari?” "Apa tugas pertama yang harus diselesaikan dalam pembelajaran interdisipliner ini?” "Kapan menyerahkannya?" Yang paling menarik adalah: "Apabila hasil belajar pada satu mata pelajaran tidak bagus, apakah hal tersebut juga berpengaruh pada dua mata pelajaran lainnya?” Pertanyaan ini mengindikasikan kesadaran adanya interkoneksi antar ketiga mata pelajaran dalam unit pembelajaran interdisipliner ini.

Tindakan pembelajaran diwarnai dengan menginvestigasi informasi-informasi penting yang berhubungan dengan materi pembelajaran utama (novel) serta materi lain pada pelajaran terkait. Tindakan eksploratif ini bertujuan membentuk pengetahuan awal (skema). Pengetahuan awal ini merupakan dasar pijakan subjek penelitian atas keberhasilannya dalam pelajaran teknologi komputer dan karya visual. Kegiatan riset/investigasi di lain pihak juga meningkatkan kemampuan kognitif tentang hal-hal menarik yang tidak dibicarakan dalam novel tersebut. Antara lain bahwa kaum wanita muslim dari suku Hui (setting cerita) memiliki cara yang unik dalam membedakan status perkawinan. Kerudung (jilbab) putih dikenakan bagi yang telah menikah, kerudung hijau, dipakai oleh yang belum menikah.

Secara kesuluruhan, baik aktivitas subjek penelitian maupun pendidik sudah menunjukkan keaktifan. Hal signifikan diindikasikan oleh perubahan peranan pendidik (guru) pada siklus ini. Guru lebih banyak bertindak sebagai mediator dan fasilitator. Kegiatan belajar satu arah dalam bentuk ceramah seperti sebelumnya, sudah tidak tampak dan digantikan dengan kegiatan diskusi kelas. Namun suasana pembelajaran belum sepenuhnya kondusif, karena 107 subjek penelitian dikumpulkan dalam satu area (hall). Di satu sisi, subjek penelitian memperlihatkan kegembiraan lewat komentar dan ekspresi wajah karena dapat belajar di luar kelas. Namun di sisi lain, timbul keramaian karena berbicara satu dengan lainnya. Hal ini kurang diantisipasi tim peneliti pada tahap persiapan.

Hasil evaluasi siklus satu diukur dengan tes informasi untuk mengetahui sejauh mana subjek penelitian memahami isi cerita novel dari Bab 1-10. Hasilnya adalah sebagai berikut.

Tabel 4. Perorelah rerata skor kuis siklus 1

\begin{tabular}{ccc}
\hline Kelas & $\sum$ Skor Kuis & Skor $\geq \mathbf{6 . 5}$ \\
\hline 10 A & 5.9 & $53 \%$ \\
10 B & 7 & $50 \%$ \\
10 C & 6.7 & $60 \%$ \\
10 D & 7 & $55 \%$ \\
10 E & 6.5 & $58 \%$ \\
\hline
\end{tabular}

Tabel 4 menunjukkan, di antara kelima kelas, kelas 10B dan $10 \mathrm{D}$ memiliki rerata tertinggi (7), sedang kelas 10A memiliki rerata terendah (5.9). Di lain pihak, kelas 10C yang memililiki rerata 6.7, sebanyak 60\% diantaranya memperoleh skor kuis di atas atau sama dengan 65 (nilai standar ketuntasan belajar). Sedang kelas 10B hanya 50\% yang memperoleh skor di atas atau sama dengan 65 . Rata-rata jumlah siswa kelima kelas yang memperoleh skor kuis lebih besar dari 65 adalah 55.2\%. Dari angka prevalensi ini dapat disimpulkan baru setengah siswa yang memahami cerita dengan baik. 
Berdasarkan temuan pada Siklus 1, dalam diskusi antara peneliti dan kolaborator, diputuskan untuk melakukan sejumlah perbaikan untuk meningkatkan pembelajaran pada siklus selanjutnya, yaitu: membentuk teaching team pengajar sastra kelas $\mathrm{X}$ dengan pembagian tugas yang jelas tiap tatap muka untuk menciptakan kondisi belajar yang kondusif, serta mengaji ulang silabus dengan merancang hubungan prasyarat antarmata pelajaran sehingga subjek penelitian dapat semakin menyadari keterkaitan interdisipliner serta memberikan penguatan (motivasi) kepada subjek penelitian.

\section{Siklus 2}

Persiapan siklus 2 ditandai dengan pembentukan teaching team dan revisi silabus untuk menghindari kesan tugas yang tumpang tindih antarmata pelajaran. Sebaliknya penugasan dibuat dalam hubungan hirarki. Artinya, tanpa memiliki pengetahuan, ketrampilan yang memadai dari satu mata pelajaran, maka subjek penelitian akan menemukan hambatan pada mata pelajaran terkait. Dengan demikian, diharapkan, subjek penelitian merasa tertantang untuk mencapai tujuan pembelajaran serta melakukan segala daya upaya demi kesuksesan belajarnya. Ini merupakan bagian dari motivasi yang diberikan. Salah satu dampak teaching team dalam KBM siklus II ini adalah penyampaian materi pelajaran lebih tersruktur dan pendidik terlihat lebih siap dan percaya diri dalam menyajikan materi. Pembagian tugas serta tanggung jawab yang jelas, memungkinkan pendidik untuk melakukan eksplorasi yang lebih dalam terhadap materi yang disampaikan.

Kegiatan pembelajaran pada siklus 2 difasilitasi oleh sumber materi sekunder berupa film dokumenter mengenai kehidupan tokoh utama dalam novel yang dibahas. Media pembelajaran ini, memberikan kontribusi signifikan terhadap pemahaman isi cerita serta merangsang kemampuan imajinatif subjek penelitian untuk menghasilkan gambaran atau sketsa wajah yang lebih projektif dan kongkret mengenai tokoh utama dalam cerita. Hal ini diindikasikan pada sketsa komik yang dihasilkan oleh subjek penelitian pada pelajaran teknologi komputer serta seni visual. Melalui media pembelajaran ini, siswa secara sadar dapat melihat relevansi hubungan antarmata pelajaran. Hubungan yang sama juga didemonstrasikan dalam pelajaran seni visual.

Dengan menggunakan metode direct instructional, guru mencontohkan bagaimana membuat sketsa wajah, ekspresi dan gerak tubuh dengan mengaplikasikan prinsip-prinsip proporsional dalam seni. Pengetahuan serta keterampilan ini tidak saja dapat membantu subjek penelitian dalam menghasilkan sketsa komik strip yang projektif, tetapi juga sekaligus memotivasi mereka untuk melihat kembali bagian-bagian penting (hal-hal detail) dalam novel yang hendak divisualisasikan. Secara tidak langsung, siswa kembali mempelajari novel atas inisiatif sendiri, tanpa keterpaksaan atau karena ditugaskan oleh guru.

Keaktifan subjek penelitan pada siklus 2 ini ditandai dengan ketepatan waktu dalam mengumpulkan dan menyelesaikan tugas (82.5\%). Tingginya minat belajar juga dapat terlihat saat subjek penelitian menerapkan metode belajar kolaborasi tipe jigsaw saat mempelajari novel (Bab 1020). Pertukaran informasi yang terjadi antaranggota kelompok memungkinkan peserta didik untuk memahami tiap bab secara menyeluruh, karena sebelumnya, tiap bab telah dibahas secara mendetail dalam focus group. Dalam diskusi kelompok tersebut, masing-masing anggota memberi kontribusi berupa informasi-informasi yang penting dalam cerita dan pada kesempatan ini, terlihat juga aktivitas tanya jawab dan saling memberi tanggapan. Pada siklus ini, aktivitas pembelajaran terjadi bersamaan dengan interaksi sosial di dalam kelompok. Hal ini sesuai dengan teori Vigotsky (Asri, 2005) yang menekankan hakikat sosial dalam pembelajaran. Pembelajaran itu terjadi saat siswa bekerja sama menangani tugas yang berada pada zona perkembangan terdekatnya.

Evaluasi pada siklus II dilakukan dengan variasi yang berbeda dari siklus 1. Pengukuran hasil belajar sastra pada siklus II dilakukan dengan cara lisan dan tingkatan tes yang diujikan berupa konsep. 
Tabel 5 Perolehan Skor tes lisan

\begin{tabular}{ccc}
\hline Kelas & $\sum$ Skor tes lisan & Skor $\geq \mathbf{6 . 5}$ \\
\hline 10 A & 6.5 & $65 \%$ \\
10 B & 7 & $62 \%$ \\
10 C & 7.1 & $70 \%$ \\
10 D & 7.2 & $63 \%$ \\
10 E & 7.1 & $66 \%$ \\
\hline
\end{tabular}

Tabel 5 memperlihatkan kelas 10D mencapai rerata tertinggi dengan skor 7.2, sedangkan kelas $10 \mathrm{~A}$ skor mencapai rerata terendah dengan skor 6.5. Walaupun tidak terjadi peningkatan nilai rerata pada kelas 10B, namun terdapat peningkatan $12 \%$ terhadap jumlah siswa yang mencapai skor di atas nilai ketuntasan belajar. Demikian juga dengan kelas lainnya. Dengan demikian pada siklus kedua ini, dapat disimpulkan rata-rata siswa yang mencapai ketuntasan belajar dari kelima kelas dalam penelitian tindakan ini adalah 65.2\%. Walaupun pencapaian optimal belum terpenuhi dalam siklus ini, namun pemahaman dan kemampuan subjek penelitian dalam menelaah karya sastra sudah terlihat, mengingat tes yang diberikan lebih sulit satu tingkat dibanding dengan evaluasi belajar pada siklus sebelumnya.

Kendala yang dihadapi oleh peneliti dan kolaborator pada siklus ini adalah pemetaan waktu dan tenggat pengumpulan tugas. Keluhan-keluhan subjek penelitian mengenai tenggat waktu yang sempit dalam mempelajari materi serta menyelesaikan tugas merupakan hal yang akan diperbaiki pada siklus berikutnya.

\section{Siklus 3}

Aktivitas pembelajaran sastra pada siklus ketiga difokuskan pada kegiatan apresiasi. Tindakan pembelajaran pada siklus sebelumnya yang bersifat reseptif telah mempersiapkan subjek penelitian dari segi kognitif untuk lebih siap dan mantap melakukan aktivitas yang bersifat kreatif dan imaginatif pada siklus ketiga. Guna memberikan pengalaman yang nyata kepada peserta didik untuk lebih memahami dan menyelami penokohan tokoh utama, pelajaran disajikan dengan role play atau bermain peran. Dalam kegiatan itu, siswa amat antusias dan serius dalam memerankan tokoh-tokoh yang dilakoninya.

Pengalaman belajar yang sederhana ini mampu menciptakan suasana pembelajaran yang menyenangkan serta secara tidak langsung meningkatkan minat siswa pada karya sastra yang dipelajari. Dalam role play tersebut, secara berkelompok subjek penelitian diminta untuk melakonkan peristiwa yang tidak dijelaskan secara detail dalam cerita. Tantangan ini mengharuskan mereka menggunakan ketrampilan berpikir logis serta imaginatif. Salah satu adegan menarik yang ditampilkan adalah pembelaan diri tokoh utama di hadapan ibunya saat diminta untuk berhenti sekolah dengan alasan keuangan tidak memungkinkan dan karena isu gender yang diskriminatif.

Dengan kegiatan role play, peserta didik tidak hanya mampu mengulas isu-isu diskriminatif dalam cerita, tetapi juga menghayati perannya dengan baik. Boen Oemarjati (1988) menegaskan bahwa dalam kata apresiasi terkandung makna, "tanggapan ataupun pemahaman sensitif" seseorang terhadap karya sastra. Aspek afektif yang diindikasikan oleh peserta didik telah mensinyalkan kemampuan apresiasi yang cukup baik. Hasil nyata dari kemampuan apresiasi ini diperlihatkan melalui resensi novel. Dalam tugas tersebut, siswa tidak hanya dapat mengupas kelebihan dan kekurangan karya yang dibahasnya, tetapi juga dapat menuliskan, manfaat apa yang dapat diperoleh pembaca, yang sebagian besar merupakan pengalaman membaca yang telah mereka rasakan. Dalam hal ini sudah terjalin "komunikasi" antara peserta didik dengan sumber belajar yang berkontribusi terhadap pembelajaran yang bermakna. 
Pada siklus ketiga ini, kepada peserta didik diberikan pengalaman belajar yang berbeda dengan menghadirkan praktisi yang berkompeten di bidang komik. Lewat kegiatan workshop komik tersebut, secara kognitif, subjek penelitian dibekali dengan informasi-informasi menarik tentang komik. Dalam ranah psikomotorik, mereka mempraktekkan cara membuat komik strip dan dampak afektifnya menimbulkan kesan positif terhadap pembelajaran interdisipliner. Kegiatan pembelajaran ini sekaligus membangun kemampuan berpikir asosiatif dalam hal menghubungkan dan menerapkan pengetahuan dan keterampilan yang diperoleh dari workshop ke dalam pembelajaran seni visual dan teknologi komputer. Interkoneksi inilah yang menciptakan suatu pembelajaran yang bermakna. Temuan ini sejalan dengan teori kognitif.

Evaluasi hasil belajar pada siklus ketiga diukur melalui resensi novel. Hasil yang peroleh adalah sebagai berikut:

Tabel 6 Perolehan Skor resensi

\begin{tabular}{ccc}
\hline Kelas & $\sum$ Skor resensi & Skor $\geq \mathbf{6 . 5}$ \\
\hline 10 A & 6.9 & $70 \%$ \\
10 B & 7.2 & $69 \%$ \\
10 C & 6.9 & $73 \%$ \\
10 D & 7.1 & $68 \%$ \\
10 E & 7.3 & $72 \%$ \\
\hline
\end{tabular}

Tabel 6 menunjukkan peningkatan pemahaman serta kemampuan apresiasi peserta didik pada siklus ketiga. Skor resensi tertinggi dicapai oleh kelas 10E dengan rerata 7.3, sedangkan skor rerata terendah adalah kelas 10A (6.9). Pada siklus ketiga telah terjadi peningkatan skor rerata atas hasil belajar. Peningkatan ini terjadi karena penerapan multi evaluasi serta variasi metode pembelajaran. Tidak ditemukan kendala-kendala berarti pada siklus ketiga. Sehingga peneliti sepakat untuk mempertahankan keberhasilan-keberhasilan yang telah dicapai.

\section{Siklus 4}

Keberhasilan penelitian tindakan kelas ini telihat dari siklus keempat. Kegiatan pembelajaran memasuki tahap produktif. Suasana pembelajaran yang efektif dan menyenangkan telah tercipta. Dalam pelajaran bahasa dan sastra, minat siswa dalam menyelesaikan tugas proyek secara berkelompok sangat tinggi. Mereka ditantang untuk menciptakan sebuah karya visual yang berhubungan dengan novel yang dipelajari. Sebagian besar kelompok bahkan mengejakan tugasnya di luar jam pelajaran. Dalam pelajaran teknologi, penggunaan perangkat lunak (software) comics life juga telah menghadirkan kondisi belajar yang menyenangkan. Sedangkan dalam pelajaran seni visual, peserta didik menikmati kegiatan belajar dengan melakukan sketsa di atas media kanvas dan berekperimen dengan menggunakan akrilik.

Berdasarkan hasil implementasi dari berbagai siklus, diketahui pada siklus terakhir (keempat), data yang terkumpul telah menunjukkan adanya perubahan positif terhadap peningkatan pembelajaran bahasa dan sastra, khususnya kemampuan apresiasi sastra. Kemajuan pembelajaran juga terjadi dalam mata pelajaran teknologi komputer serta seni visual. Hasil angket yang dikumpulkan oleh siswa mencatat 3 temuan penting. Pertama, secara kognitif pembelajaran interdisipliner berkontribusi signifikan terhadap pemahaman materi (75\%). Kedua, model pembelajaran ini meningkatkan kemampuan berbahasa baik secara lisan maupun tulisan. Ketiga, secara afektif siswa merasa puas dan tertantang dalam mencapai tujuan pembelajaran (90\%). Sebagai dampak pengiring, ketrampilan berkolaborasi, berpikir kritis, dan berwawasan luas (holistik) semakin terasah (74\%). 


\section{PENUTUP}

Pembelajaran interdispliner merupakan salah satu solusi dalam menciptakan kondisi belajar yang mengasikkan dan menyenangkan serta memberikan pengalaman belajar yang bermakna. Penerapan pembelajaran interdispliner (bahasa dan sastra, teknologi komputer serta seni visual) di kelas X BINUS International School Simprug Jakarta cukup efektif. Telah terjadi peningkatan hasil belajar yang diindikasikan oleh (1) peningkatan aktivitas belajar siswa dan guru, (2) peningkatan hasil belajar siswa serta (3) peningkatan jumlah subjek penelitan yang tuntas belajar. Selain perolehan hasil belajar yang bersifat instruksional, penerapan model pembelajaran interdisipliner juga memberikan peningkatan terhadap dampak pengiring (nurturant effect) berupa kemampuan kolaboratif, berpikir holistik serta meningkatkan minat untuk membaca sastra. Pemilihan tema 'kreasi dan rekreasi' cukup sesuai dengan alasan: (1) tidak terlalu luas namun dapat mengakomodir tiga mata pelajaran dari disiplin ilmu yang berbeda secara seimbang (2) dapat meningkatkan kemampuan berpikir pada tingkat yang lebih tinggi yaitu menganalisis dan mensintesis (3) dapat diukur dan hasilnya dapat dilihat secara nyata.

Keberhasilan pembelajaran ditunjang oleh faktor (1) multi evaluasi yang terdiri dari tes dan non tes; (2) Pengalaman belajar yang bervariatif serta suasana belajar di luar kelas; (3) Tersedianya sumber informasi (internet), sumber belajar sekunder (workshop dan jumpa penulis) serta media pembelajaran yang menunjang, mempekaya dan mempermudah pengembangan wawasan; (4) karakteristik pembelajaran interdisipliner yang menekankan pada kemampuan eksploratif dan elaboratif, kemampuan analitik (menguraikan),serta kemampuan asosiatif (merelasikan). Melalui pembelajan interdispliner, telah terjalin interaksi yang positif antara guru dengan guru, guru dengan peserta didik, peserta didik dengan peserta didik, serta pembelajar dengan sumber belajar dalam konteks yang lebih bermakna. Peserta didik telah mampu mengasoiasikan hubungan antarpelajaran dalam perspektif yang holistik serta merasa puas dengan hasil belajar sehingga dampaknya dapat bertahan lama.

Sebagai pengembang dan pelaksana pembelajaran interdisipliner di lapangan, guru dituntut untuk terus memperbaharui pengetahuan serta melakukan refleksi untuk meningkatkan kualitas pengajaran. Melibatkan lebih banyak varian mata pelajaran dalam pembelajaran interdisipliner sehingga dapat mengagas permasalahan yang lebih menantang siswa untuk mengolah kemampuan berpikir dan memecahkan persoalan. Mematahkan stigma negatif terhadap pembelajaran interdisipner yang melelahkan dan merepotkan, sebab kerepotan yang tercipta justru kerepotan yang mengasikkan dan menyenangkan.

\section{DAFTAR PUSTAKA}

Ardianto. (2007). Pembelajaran Sastra sebagai sarana Pengembangan Daya nalar Siswa. IQRA 57. Volume 3, Januari-Juni 2007.

Budiningsih, A. (2005). Belajar dan Pembelajaran. Jakarta: Rineka Cipta.

Fogarty, R., (1999), "Architects of the Intellect," Educational Leadership, Vol. 57, No. 3, pp. 76-78.

Herfanda, A. Y. (2007, April 10). Pengajaran Sastra Berpusat pada Karya Sastra. Makalah seminar Pengajaran Bahasa dan Sastra. HMBSI FPBS UPI: Bandung. Diunduh dari http://cabiklunik.blogspot.com/2007/04/esai-menuju-format-baru-pengajaran.html 
Indrawati, (2009). Model Pembelajaran Terpadu di Sekolah Dasar Untuk Guru SD. Jakarta: Pusat Perkembangan dan Pemberdayaan Pendidik dan Tenaga Kependidikan Ilmu Pengetahuan Alam untuk Program Bermutu.

Ismail, T. (2009, Juni 7). "Banyak Membaca Buku dan Terus Berlatih Menulis: Mengejar Ketertinggalan Lebih Setengah Abad Lamanya." Makalah Seminar Nasional: Pengembangan Model Pembelajaran Sastra Yang Komunikatif Kreatif, Universitas Negeri Semarang: Semarang.

Kunandar. (2008). Langkah Mudah Penelitian Tindakan Kelas sebagai Pengembangan Profesi Guru. Jakarta: Rajawali Press

Oemarjati, B. S. (1988). Pembinaan Apresiasi Sastra dalam Proses Belajar Mengajar. Makalah Seminar Pengajaran Bahasa dan Sastra Indonesia, Jakarta: IKIP.

Suharianto, T. (2009, Juni 7). Pengajaran Sastra... Oh, Pengajaran Sastra...." Makalah Seminar Nasional: Pengembangan Model Pembelajaran Sastra Yang Komunikatif Kreatif, Universitas Negeri Semarang: Semarang.

Sukandi, U. (2001). Belajar Aktif dan Terpadu: Apa, Mengapa, dan Bagaimana? Jakarta: The British Council.

Sukayati. (2004). Pembelajaran Tematik di SD Merupakan Terapan dari Pembelajaran Terpadu. Yogyakarta: DEPDIKNAS PPPG Matematika.

Trianto. (2007). Model Pembelajaran Terpadu dalam Teori dan Praktek Jakarta: Prestasi Pustaka.

Wijaya, P. (2007, November 3). Pengajaran Sastra. Diunduh dari http://putuwijaya.wordpress.com/2007/11/03/pengajaran-sastra/3. Akses 25 Januari 2010

Y, T. H. (2010, April 17). Kesalahan Berbahasa Dilakukan Bersama. KOMPAS [Jakarta] 